\title{
A linguagem gráfica de quem não vê: primeiros resultados empíricos ${ }^{1}$
}

\section{Marcelo Santos}

\section{Resumo}

Este artigo apresenta os primeiros resultados empíricos de projeto de pesquisa iniciado no ano de 2008, dedicado a investigar a produção de imagens por pessoas cegas. Há um duplo objetivo: de um lado, questionar certos cânones da linguagem visual, evidenciando que vários dos seus princípios são apreendidos sem o auxílio da visão, não sendo, pois, exclusivamente característicos da visualidade; de outro lado, busca-se propor metodologias para a construção de imagens táteis, acessíveis bilateralmente a deficientes visuais e videntes. Os dados aqui exibidos foram gerados em estudo qualitativo realizado com um único sujeito cego. Este foi convidado a desenhar representações imagéticas, diagramáticas e metafóricas, interpretadas neste escrito com 0 auxílio da semiótica peirceana.

\section{Palavras-Chave}

Cegueira. Linguagem gráfica. Semiótica peirceana.

Marcelo Santos I para_marcelo@yahoo.com.br Doutor em Comunicação e Semiótica pela Pontifícia Universidade Católica de São Paulo, Brasil. Professor do Programa de Mestrado em Comunicação da Faculdade Cásper Líbero, Brasil.

\section{0 desejo por dados empíricos: recrutamento, material e método e pré-teste}

Em ocasiões anteriores, 0 autor (Santos, 2009; 2012; 2015a) abordou conceitualmente ligações semióticas entre os processos comunicativos realizados pelos sistemas visual e tátil, sugerindo, principalmente, duas coisas: 1 ) que tais sistemas operam seguindo processos lógicos distintos e complementares, a saber, dedução e indução, respectivamente; 2) a existência de certa equidade entre os dados providos à mente pelas experiências visual e háptica, ou, dito de outro modo, a suposição de que olhos e pele percebem as quinas e bordas dos objetos e do espaço de maneira similar, do que decorre uma potencial equivalência entre as linguagens da visualidade e da tatilidade. Neste artigo, o objetivo é outro: confrontar essas hipóteses lançadas com cinco estudos de caso inéditos, todos desenvolvidos com um único sujeito cego no ano de 2012. Trata-se de uma pesquisa em curso, realizada desde 2008, cujos primeiros resultados são agora trazidos a público 
e ajudarão a problematizar certos cânones adotados na delimitação do que se nomeia "comunicação visual".

Cumpre, já nesta introdução, relatar o seguinte: estes experimentos iniciais foram idealizados para serem feitos com sujeitos cegos e videntes, divididos em quatro grupos, cada qual composto por seis sujeitos - três cegos e três videntes -, organizados segundo similaridades etárias - 10 , 20, 30 e 40 anos -, econômicas e grau de instrução formal. A ideia era ter, tanto quanto possível e a despeito das diferenças perceptivas individuais, alguma uniformidade entre os futuros integrantes do estudo reunidos nos diferentes conjuntos citados. Os deficientes visuais e os dotados de visão deveriam produzir desenhos a partir dos mesmos objetos ou grupos de objetos. Tais desenhos, a posteriori, seriam intercambiados, de modo a permitir aos videntes a análise das representações produzidas pelos deficientes visuais, comparando-as às suas, e vice-versa. Acreditava-se que, ao contrapor as representações obtidas aos relatos dos grupos, alcançar-se-iam dados capazes de manifestar, na prática, alguma correspondência ou inadequação entre a hipótese de equivalência semiótica da comunicação visual à tátil e aquilo que, de fato, ocorre.

Houve, para surpresa do pesquisador, acostumado a realizar estudos empíricos, um problema grave de recrutamento. A maior parte dos 45.623.919 deficientes visuais do Brasil, conforme dados divulgados pelo Censo Demográfico realizado em 2010, pelo Instituto Brasileiro de Geografia e Estatística (IBGE), possui baixa visão ${ }^{2}$. Efetivamente cegos, ainda de acordo com a citada pesquisa, seriam 528.624 pessoas, aproximadamente $1,15 \%$ do total de deficientes visuais, ou $0,28 \%$ da população do país, então estimada em 190.755.799 habitantes. Encontrar sujeitos cegos e dispostos a participar do estudo, residentes na cidade de São Paulo, local da pesquisa, não seria, pois, trabalho dos mais fáceis. 0 pesquisador começou, então, verdadeira peregrinação por instituições dedicadas a prestar auxílio a pessoas com deficiência, a exemplo de centros culturais, profissionalizantes e, sobremaneira, aqueles dedicados à reabilitação.

Agradeço à Fapesp, pelo financiamento (Processo 09/50762-9); Lucia Santaella, Winfried Nöth e John M. Kennedy, pelas discussões.

Conforme discutido em outra ocasião (Santos, 2008, p. 109), sabe-se que a Organização Mundial de Saúde (OMS) sugeriu, em 1980, a classificação das deficiências visuais a partir da medida da acuidade - precisão - visual. Desde então, esse tem sido o parâmetro mais utilizado para aferir a "visão útil" dos indivíduos, tanto que, na literatura especializada, observa-se que as definições dos termos relacionados à deficiência visual são muito parecidas, e sempre fundamentadas nesse elemento: a capacidade de distinguir os detalhes dos objetos captados pelos olhos. Partindo da acuidade como balizador, dois grandes grupos são então tipificados: os dotados de baixa visão ou visão subnormal e os cegos. No primeiro caso, englobam-se as pessoas onde se conserva uma capacidade visual, ainda que extremamente limitada, como a habilidade de distinguir contornos, sombras ou pontos de luz, permitindo-se o planejamento ou execução de uma tarefa com o auxílio da visão. Já a cegueira, conceito unificado em quase todos os países ocidentais, indica alguém com acuidade visual insignificante ou até nula; um olho é cego quando sua acuidade visual com correção é 1/10 (0,1), ou cujo campo visual se encontre reduzido a $20^{\circ}$, ou ainda menos. 
No segundo semestre de 2009, passado um ano de tentativas de recrutamento, nas quais se promoveram visitas quinzenais ou mensais às mais distintas instituições, troca de e-mails e, principalmente, telefonemas a incomensuráveis sujeitos em potencial, ou responsáveis legais por sujeitos em potencial, no caso dos menores de idade, e quase nada havia sido conseguido. De um lado, havia o problema financeiro e 0 de mobilidade dos sujeitos, em certa medida associados. Do outro lado, o medo do convite para desenhar. Conforme apontam números da Organização Mundial de Saúde divulgados na década passada, há uma conexão direta entre cegueira e pobreza, ou, precisamente, entre as deficiências visuais e a falta de assistência médica adequada: "Estudos populacionais indicam baixa prevalência da cegueira infantil, de 0,2 a 0,3 por 1.000 crianças em países desenvolvidos, e de 1,0 a 1,5 por 1.000 crianças em países em desenvolvimento" (Brito e Veitzman, 2000). No Brasil, os dados se repetem, e a maior parte dos deficientes encontra-se na Região Nordeste, notadamente nos estados do Rio Grande do Norte e da Paraíba, possuidores de baixos indicadores de desenvolvimento social, quando comparados a outras unidades federativas brasileiras (IBGE, 2010).

Assim, muitas vezes, os deficientes visuais, cegos e dotados de baixa visão considerados, têm recursos financeiros escassos. Isso, associado às dificuldades de mobilidade que são inerentes àqueles que, sem a orientação visual, enfrentam grandes entraves para se deslocar em um espaço pouco adaptado às suas necessidades (cf. Santos, 2009), sobretudo em uma cidade com as proporções de São Paulo e o seu problemático transporte público, tornava difícil encontros entre o pesquisador - também usuário de ônibus e metrô -, morador da região central, e os sujeitos, normalmente residentes em áreas periféricas. Para as pessoas cegas contatadas, por vezes, deslocarse alguns quilômetros de suas casas até um local geograficamente central ou mesmo a alguma estação de metrô, a fim de facilitar um encontro presencial, era tarefa quase hercúlea. Precisavase marcar horários em pontos de ônibus, esperar os potenciais participantes deficientes e, ainda, por repetidas ocasiões, depender da generosidade dos amigos, colegas de trabalho e familiares que se dispusessem a acompanhá-los, inclusive no regresso às suas casas.

Além da problemática logística apontada, havia 0 segundo entrave indicado e ainda não esclarecido: o medo de se desenhar. Ao serem abordados com um convite para fazer desenhos, os cegos encontrados pelo pesquisador, via de regra, mostravam-se descrentes e desconfiados, mesmo quando lhes eram relatadas experiências catalogadas na literatura. Então, o autor deste artigo, munido de um dispositivo artesanal composto por papel/tela de mosquiteiro, pedia que aquelas pessoas experimentassem 0 aparato. Elas ficavam felizes, por vezes emocionadas em notar sua capacidade de marcar graficamente 0 papel, mas julgavam-se incapazes de efetivamente 
desenhar, argumentando que isso era coisa para videntes; diziam, também, que nunca haviam feito qualquer espécie de coisa similar e, dominadas pelo medo de "errar", mesmo quando lhes era, tão somente, solicitado "faça o que quiser", ou "desenhe uma linha, um rabisco", declinavam sumariamente do convite para participar do estudo, dizendo, todavia, que teriam interesse em conhecer seus resultados.

0 pesquisador, aos poucos, presumiu que talvez fosse 0 caso de abandonar a pesquisa prática. Essa ideia começou a ser deixada de lado quando se descobriu a existência do volume Tactile Graphics, publicado pela designer Polly K. Edman, em 1992, através da American Foundation for the Blind (AFB). Nesse livro, classificado pelo presidente e diretor da AFB desde 1991, Carl R. Augusto (1992, p.xi), como "landmark", Edman oferta mais de 450 páginas comprometidas com a descrição panorâmica, ao modo de um handbook, de variadas metodologias destinadas à criação de imagens tangíveis, em casa ou na escola, como também de displays táteis para empresas; os exemplos fornecidos variam de simples desenhos feitos sobre folha especial para confecção de figuras em relevo a complicados diagramas digitais, destinados à impressão em máquinas capazes de produzir toda sorte de gráficos hápticos (Edman, 1992, pp. 3-4).

Através de Tactile Graphics, pôde-se ter acesso não apenas a metodologias detalhadas, mas também à informação importantíssima: a existência de "raised-line drawing boards". Segundo Edman (1992, p.15), essa tecnologia "é uma importante, se não a mais importante ferramenta gráfica para crianças deficientes visuais". Trata-se, basicamente,

de uma fina folha de borracha presa numa base firme de cartão, plástico, ou madeira. Essa 'almofada' é coberta por folha removivel e descartável de filme plástico, presa à prancheta por grampos ou colocada sobre ela ao modo de um embrulho. Uma caneta esferográfica, lápis,

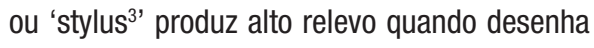
sobre 0 filme plástico. A técnica de desenho usada limita-se a diagramas lineares. Erros não podem ser apagados (Edman, 1992, p. 15).

Apesar de Edman (ibid.) afirmar que cada país, pequenas variações, tem seu próprio kit para desenho em alto relevo, nada similar foi encontrado no Brasil. Prova disso são os inúmeros trabalhos de Duarte (e.g. 1995; 2004), nos quais, objetivo de se produzir desenhos táteis com crianças e adolescentes cegos, são empregados materiais como massa de modelar, barbante ou giz de cera em relevo; nada que se assemelhe, logo, aos aparelhos descritos por Edman.

Esses últimos só foram localizados para compra entre os produtos da empresa Maxi-Aids, em cujo portfólio, segundo o site da companhia, existem mais de 6 mil itens destinados a pessoas com necessidades especiais. Infelizmente, 0 sistema online de vendas não disponibilizava entregas 
no Brasil. Nova pesquisa levou o autor a encontrar, no site da "Amazon", o mesmo material, também da Maxi-Aids. Outra vez, ao se digitar a cidade de São Paulo como destino final dos produtos, a compra tornava-se inviável. Foi necessário, assim, falar com amigos residentes nos Estados Unidos para que estes comprassem os desejados materiais e, posteriormente, os enviassem a São Paulo. A esperada remessa de 15 kits, como o da figura a seguir, chegou em agosto de 2010. Além da prancheta e da caneta stylus, estavam incluídas dezenas de folhas plásticas para produção dos desenhos.

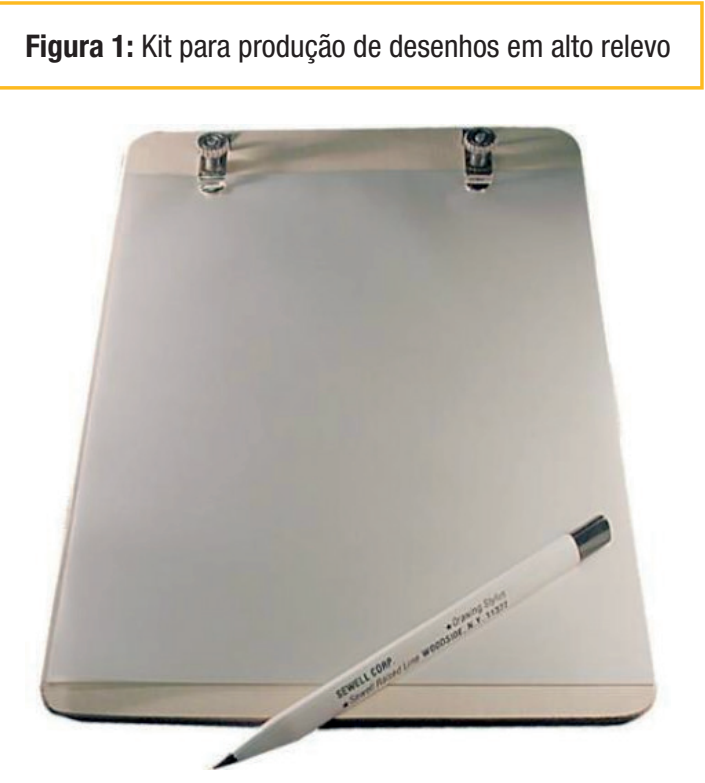

Paralelamente à aquisição dos mencionados aparatos técnicos, começou-se a resolver 0 problema do recrutamento. No final de 2009, após apresentação de trabalho e algumas discussões realizadas no $X$ World Congress of Semiotics, encontro realizado na Espanha, o autor concluiu que talvez não fizesse sentido - objetivo de comparação entre cegos e videntes - seguir a metodologia descrita na abertura desta seção. Há incontáveis estudos a respeito da linguagem visual e rica oferta iconográfica, isto é, de dados capazes de servir como subsídio para se entender o modo pelo qual os dotados de visão produzem imagens. Resolveu-se, pois, que se concentrariam os experimentos apenas em pessoas cegas, e que talvez fosse mais fácil, pelos motivos indicados nas páginas anteriores, fazer isso com 0 auxílio de alguma instituição que já contasse com frequentadores regulares cegos.

Idealizou-se, assim, converter aquela pesquisa empírica em oficina destinada, exclusivamente, a pessoas cegas. Seria a oportunidade de experimentar metodologias, isto é, de se fazer um "pré-teste" antes de se proceder à coleta de dados definitiva. Proposta finalizada, em início de 2010, 
entrou-se em contato com Daina Leyton, à época coordenadora do "Programa Igual Diferente", pertencente ao Museu de Arte Moderna de São Paulo (MAM-SP). Destinado a promover ações inclusivas a partir de experiências ligadas à arte $\mathrm{e}$ capazes de acolher pessoas com as mais diversas particularidades físicas, sensoriais e intelectuais, o citado programa, conforme dados obtidos no site do próprio museu noticiam, já contou com 2.866 participantes em seus cursos e 10.699 pessoas nas demais atividades ofertadas, a saber, palestras, oficinas, visitas e eventos variados.

Exatamente por apresentar essa proposta, 0 espaço pareceu ser bastante adequado à intenção de, em um lugar já dotado de frequentadores cegos, que para lá se locomoviam por conta própria, conduzir os experimentos pretendidos. Depois de rápida troca de e-mails e alguns encontros presenciais, nos quais o pesquisador pôde conferir in loco os trabalhos e a estrutura do museu, Daina tirou suas dúvidas sobre as intenções do estudo e fez sugestões. Definiuse, então, para o primeiro semestre de 2010, a realização da oficina direcionada à confecção de imagens sem 0 auxílio do sistema visual, intitulada "Desenho Cego", a pedido das professoras convidadas para ministrar as aulas, ambas artistas plásticas e arte-educadoras. 0 pesquisador, de início, queria fazer um curso no qual houvesse, exclusivamente, pessoas cegas sem outras condições associadas, a exemplo de problemas cognitivos; esta ideia, porém, contrariava a proposta do "Igual
Diferente" que, por princípio, acolhe ao mesmo tempo e sem distinções, em suas atividades, sujeitos dotados de psicopatologias diversas, deficiências sensoriais e físicas de todos os tipos, além daqueles que, por ausência de outra denominação, chamar-se-á de "comuns".

Ainda que sensibilizado pela possibilidade de trabalhar com turma plural de alunos, 0 pesquisador ficou temeroso de que os propósitos da oficina ligados a este artigo acabassem comprometidos, sobretudo o de fazer experimentos com pessoas cegas para a produção de desenhos. Mas no começo de abril, as aulas se iniciaram às quintas-feiras, das $10 \mathrm{~h}$ às $12 \mathrm{~h} 30$, contando com cinco deficientes visuais, outras cinco pessoas dotadas de psicopatologias ou problemas físicos as primeiras, às vezes, conjugadas aos segundos - e dois sujeitos "ordinários", o pesquisador entre eles. Guiados pela gravurista Leya Mira Brander e pela especialista em fotografia e escultura Renata Madureira, os alunos começaram, então, a experimentar, através das mais distintas metodologias, a produção de imagens táteis.

A primeira técnica empregada foi a "isogravura", ou a gravura feita sobre isopor. 0 material, bastante maleável e barato, permitia a fácil manipulação através do uso de ferramentas comuns, como canetas esferográficas e estiletes. 0s relevos produzidos, entretanto, eram grosseiros e não tinham a sutileza, por exemplo, dos traços feitos com um lápis sobre papel. Pediu-se que, para a segunda aula, fosse levado um objeto 
pessoal ou de casa, preferencialmente capaz de ser segurado com apenas uma mão. Como indicado em um famoso estudo sobre percepção háptica (Klatzky, Lederman e Metzger, 1985), o reconhecimento tátil é rápido, coisa de fração de segundos, para objetos comuns que cabem nas mãos.

Os objetos levados pelos alunos no dia marcado foram, então, desenhados no isopor e, depois, as representações resultantes circularam pela sala. Muitos alunos, ao invés de efetivamente, mão livre, rabiscar, optaram por, literalmente, contornar os artefatos por eles trazidos. Isso revelava, principalmente, insegurança e medo de desenhar algo que ninguém fosse capaz de entender. Conforme as pranchas de isopor circulavam e eram tocadas - os videntes evitavam olhá-las diretamente -, notou-se que, com bastante facilidade, os desenhos feitos eram corretamente relacionados aos seus objetos. Apesar de, como se disse, não se ter efetivamente "desenhado", mas contornado os objetos, a atividade serviu para indicar que, de fato, os contornos visualmente percebidos eram interpretados de modo similar pelo tato.

Posteriormente, resolveu-se criar uma espécie de "biblioteca tátil", composta por materiais como bolas de gude e folhas secas, colocados dentro de caixas opacas acessíveis apenas pelas mãos. Também se decidiu trabalhar, deliberadamente, estimulando os alunos a produzir desenhos em contorno, a partir do seguinte método: inicialmente, foram confeccionadas formas como quadriláteros, círculos, elipses e triângulos em material epóxi; estas, ao modo de gabaritos que podiam ser livremente combinados, orientaram as composições dos alunos que, agora, proposta didática, deveriam desenhar - ou gravar - os contornos finais de seus arranjos. Isso serviu para que cada um, videntes incluídos, pois muitos deles não desenhavam desde épocas escolares, ganhasse segurança no manejo dos materiais e na sua própria capacidade.

Logo depois, finais de abril, introduziu-se para os alunos a gravura sobre madeira. Achou-se, de início, que os videntes, muitas vezes livremente recusando as vendas ofertadas, até pelo fato de alguns possuírem psicopatologias e ficarem em estados alterados de consciência quando vendados, não se cortariam com as goivas, necessárias para gravar imagens nas placas de compensado, e que os cegos precisariam ser, constantemente, auxiliados. Na primeira aula, dois videntes sofreram pequenos machucados; nenhum dos cegos se feriu.

Um problema identificado, ainda no final de abril, foi a dificuldade para explicar as tarefas propostas aos alunos cegos. Dizer "nós hoje vamos fazer trabalho inspirado nisto ou naquilo", simplesmente, não funcionava. Renata Madureira, professora com experiência em curso de fotografia destinado a pessoas cegas, atentou, então, para a necessidade de se trabalhar com a audiodescrição, procurando, tanto quanto 
possível, ofertar verbalmente aos alunos com deficiências visuais a tradução daquilo percebido pelos olhos dos alunos videntes. A constatação parece óbvia, mas esquecê-la, questão de hábito, é muito fácil.

As aulas seguiram até o fim de junho e se mostraram bastante produtivas. Variadas gravuras, cujas matrizes de madeira ou $\mathrm{EVA}^{4}$ eram disputadas pelos alunos com deficiência visual, foram produzidas. As imagens resultantes, impressas sobre papel, eram ricamente descritas pelos alunos videntes, com auxílio das professoras, para aqueles impossibilitados de enxergá-las. Todos integrados e cada vez mais animados com as aulas, até que houve uma pausa: julho era mês de férias.

As aulas só retornaram em agosto daquele ano, outra vez, baseadas na confecção de gravuras. No começo desse mês, contudo, desembarcaram no Brasil os tão esperados kits para desenho tátil. 0 pesquisador ficou com uma unidade e doou as demais ao MAM-SP. 0 primeiro teste feito no material foi surpreendente: a caneta deslizava com extrema facilidade sobre as folhas plásticas, originando linhas finas e extremamente sensíveis ao exame das mãos; havia, em algum grau, bastante similaridade entre a atividade e um desenho visual, pois se podia sentir instantaneamente as marcas realizadas, e assim controlá-las. Desejava- se, de imediato, empregar o material nas aulas, contudo, as professoras e Daina argumentaram que mal os alunos tinham iniciado as gravuras sobre madeira e que pareciam estar gostando muito da técnica.

0 pesquisador ficou um pouco frustrado, mas acatou 0 argumento. Todo caso, a 0 final da segunda aula, realizada em 12 de agosto, testou-se 0 equipamento com três dos alunos cegos: 0 escultor Rogério Ratão, a citada artesã que havia perdido a visão, e o único sujeito no grupo dotado de cegueira precoce. Todos, invariavelmente, ficaram surpreendidos e entusiasmados. Rogério, livre classificação, adjetivou o desenho feito sobre o kit como "desenho tátil". Em 19 de agosto, fez-se a primeira experiência oficial com os equipamentos importados. Neste caso, todos os participantes, já se sentindo seguros e acolhidos pelo ambiente e uns pelos outros, optaram por desenhar sem auxílio visual, de maneira que os videntes, por escolha própria, decidiram por colocar vendas.

Os mesmos objetos - tesoura sem ponta, copo plástico descartável e tubo de tinta com formato de bisnaga, conforme pode ser observado a seguir na Figura 02 - foram entregues a todos os alunos presentes, para que fossem desenhados à mão livre ou, se muito, com 0 auxílio de réguas. 
Figura 2: Bisnaga de tinta com forma análoga à que foi entregue aos alunos.

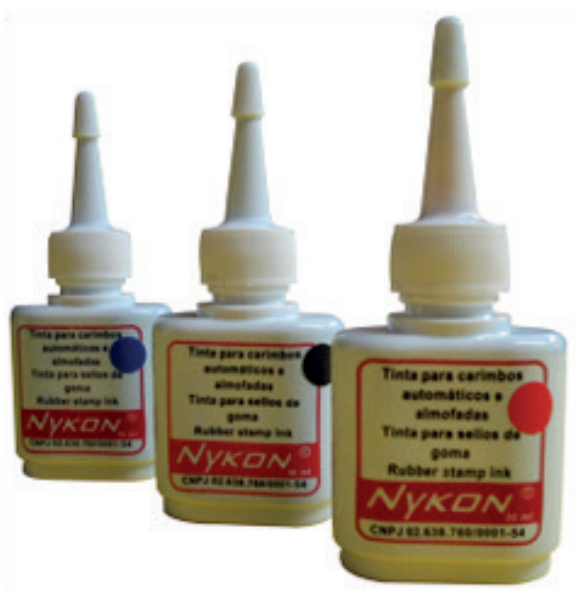

Figura 3: Desenho com o Kit importado.

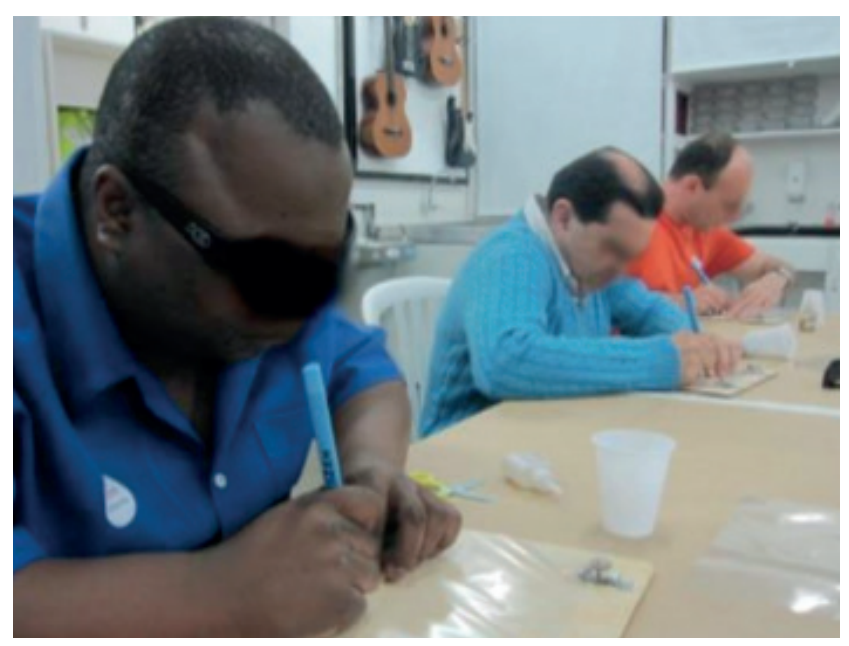

Figura 4: Desenho com o Kit importado.

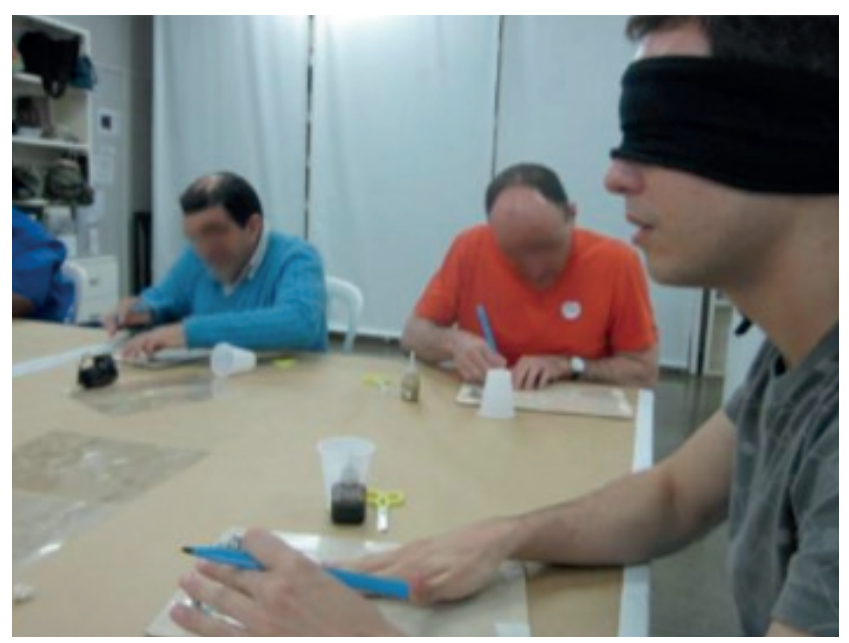


A maioria dos desenhos obtidos, todos

espontaneamente realizados com linhas em contorno, ficou bastante próxima dos objetos originais, conseguindo gerar imagens dotadas de iconicidade imagética com seus referentes (CP 2.277), capazes de representar com bastante fidelidade as suas formas. Os signos táteis obtidos, desenhos realizados com caneta sem tinta sobre folha plástica transparente, eram, muitas vezes, melhor interpretados pelo toque do que com os olhos, mesmo para os alunos videntes.

No dia 26 de agosto de 2010, novamente usando 0 kit para desenho em contorno, as professoras convidaram os alunos a ouvir a composição de Debussy "Clair de Lune", música calma tocada em piano, e a desenhá-la. Passado o alvoroço inicial, todos se concentram e realizaram representações mais ou menos metafóricas, de teclas de piano e pianos - algum grau indexicais - a paisagens como casas em montanhas, cuja interpretação ordinária socialmente convencionada no 0cidente é a de "calmaria", "tranquilidade", "paz", palavras usadas pelos participantes para descrever as representações criadas.

0 pesquisador esteve presente em mais uma aula, realizada no dia 2 de setembro, na qual se voltou a fazer gravuras sobre madeira. Logo depois, viajou para estágio de pesquisa na Universidade de Toronto, munido dos dados obtidos no MAM-

SP. Tais dados foram discutidos com diversos pesquisadores no Canadá, integrantes de grupo de estudos coordenado por John M. Kennedy, um dos maiores especialistas do mundo em desenhos feitos por pessoas cegas.

Figura 5: Aula do curso "Desenho Cego" no MAM-SP/Confecção dos gabaritos geométricos

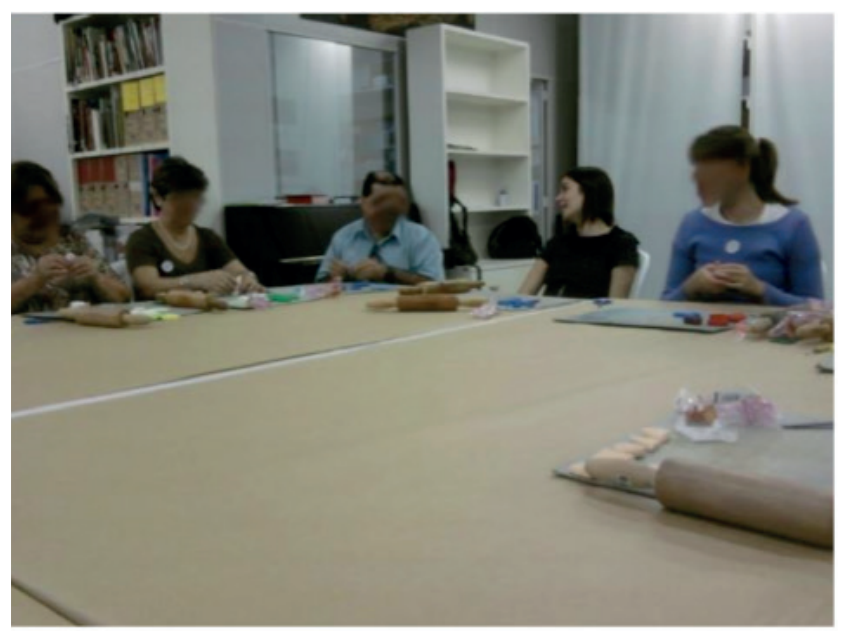


Figura 6: Aula do curso "Desenho Cego" no MAM-SP/Confecção dos gabaritos geométricos.

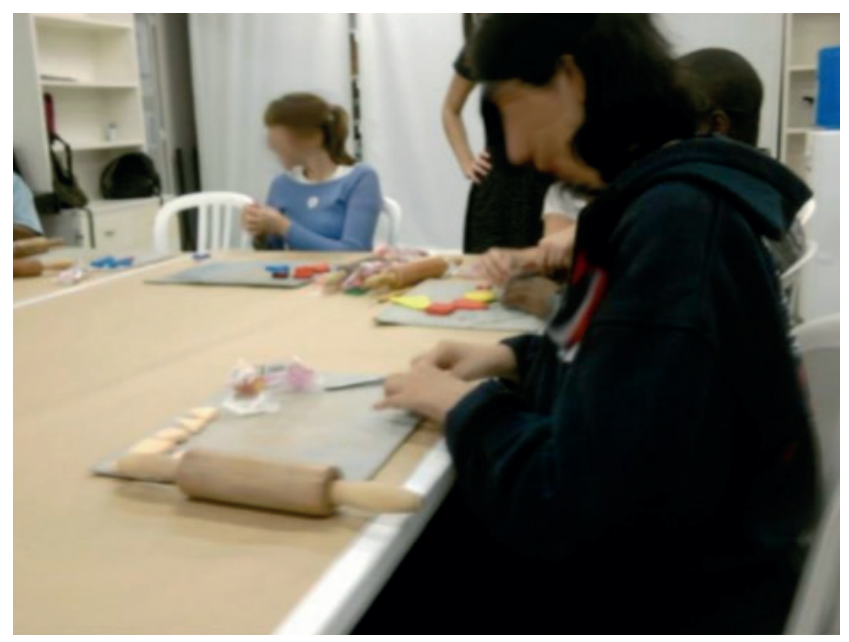

Figura 7: Aula do curso "Desenho Cego" no MAM-SP/Xilogravura.

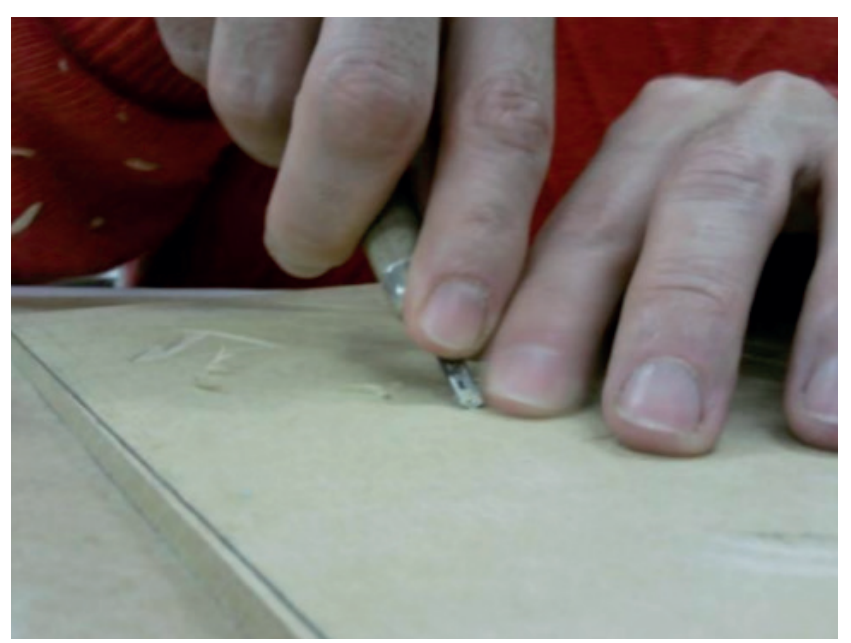

\section{Cinco estudos de caso}

Durante estágio no Canadá, 0 autor, em certa ocasião, perguntou ao seu supervisor se ele não julgava problemático fazer estudos cognitivos com um único sujeito, como se podia encontrar em vários trabalhos publicados pelo próprio John M. Kennedy (e.g. Kennedy e Juricevic, 2006). A resposta foi objetiva e certeira: "Nome do pesquisador, é melhor ter os melhores dados de um sujeito que faça a diferença a dados de vários sujeitos incapazes de atingir os objetivos da pesquisa almejada. 0 importante é a qualidade dos dados. As generalizações, sempre, são apenas hipotéticas. Se você não for testar uma vacina, pequenos grupos, ou mesmo um único sujeito, são mais que suficientes".

De volta ao Brasil, finais de março de 2011, 0 pesquisador, então, resolveu que tentaria formar um pequeno grupo, composto por três ou cinco sujeitos cegos congênitos, a fim de proceder à 
parte prática da sua pesquisa. Encontrando-se os almejados sujeitos, eles seriam convidados a confeccionar representações que tentassem representar seus objetos através de similaridade no sentido semiótico peirceano, ao modo de 1) hipoícones imagéticos, a mimese da qualidade do objeto; 2) hipoícones diagramáticos, ou a tentativa de analogia com as relações internas/estruturais do objeto representado; e, ainda, 3) hipoícones metafóricos, cuja semelhança com o objeto baseiase em convenções (CP 2.277). Estabeleceram-se os seguintes experimentos:

1) Imagem: três objetos, de formatos distintos e preferencialmente orgânicos, escopo de fomentar 0 desenho à mão livre, deveriam ser representados o mais próximo possível dos originais.

2) Diagrama: 0 deficiente visual deveria fazer um mapa de percurso ou ambiente por ele conhecido, que pudesse ser examinado pelo pesquisador para a comparação signo/objeto.

3) Metáfora: seguindo a experiência desenvolvida no MAM-SP, uma música teria que ser desenhada pelo participante do estudo.

Em todos os casos, diante dos resultados obtidos no MAM-SP, definiu-se que seriam usados como material os kits importados para a feitura de desenhos hápticos. Quanto ao método, 0 pesquisador se encontraria individualmente com cada sujeito, em lugares da preferência deles, para a condução dos experimentos. Resolveu-se que, no caso dos signos metafóricos, seria gravada descrição falada dos sujeitos sobre 0 signo desenhado. Ação correlata não seria tomada com relação às representações predominantemente imagéticas e diagramáticas, pois a fala pouco acrescentaria às discussões; no caso das metáforas, porém, pareceu importante, pensandose que este tipo de signo, predominantemente de terceiridade, tem maior grau arbitrário, e ouvir as intenções pretendidas e confrontá-las aos resultados materializados nos desenhos privilegiaria a melhor compreensão do tipo de relação semiótica intencionada pelos sujeitos.

As imagens resultantes seriam, em todos os casos, exclusivamente analisadas pelo autor deste artigo, já que, ao invés de reunir o grupo, pelas dificuldades de mobilidade relatadas noutro momento, se trabalharia, individualmente, com cada sujeito. Além disso, não existiria, no caso dos diagramas, um mesmo objeto - percurso ou ambiente - examinado por todos os participantes, o que comprometeria paralelismos.

0 pesquisador estabeleceu contato com várias instituições e amigos na busca por indivíduos. Conseguiu encontrar apenas duas pessoas que aceitaram fazer parte do estudo, uma mulher de 37 anos, residente em Diadema, Região Metropolitana de São Paulo, cega desde os três meses de idade, e um rapaz de 26 anos, morador 
do bairro paulistano das Perdizes, cego desde os dois anos. Como nenhum dos sujeitos havia tido contato prévio com os kits para desenho em relevo, 0 pesquisador teria que se dirigir às suas casas para possibilitar a experiência com 0 material.

0 rapaz foi o primeiro a ser visitado. Ele logo se apaixonou pelo kit. Conseguia, com muita facilidade, usá-lo para fazer linhas retilíneas, circulares, e mesmo formas, a exemplo de quadriláteros. Esse sujeito havia estudado na "Escola Padre Chico", referência, por muitas décadas, em educação de pessoas com deficiência visual na cidade de São Paulo. A citada instituição é conhecida, de igual modo, por ter em seu currículo línguas estrangeiras e atividades usualmente pouco ofertadas a pessoas cegas ou com baixa visão, como balé clássico. Talvez isso tenha contribuído para a ausência de "medo" em tentar desenhar no material, conforme verificado no citado rapaz.

Pouco antes de visitar o segundo sujeito - a mulher de 37 anos, moradora de Diadema, então, já finais de maio de 2011-, houve uma desistência por parte da mesma em fazer parte do estudo. 0 plano foi abortado. Optou-se, ainda que descontentemente, mas sem resultar em grandes prejuízos para a pesquisa, que se trabalharia com um único sujeito.

Os experimentos foram programados para acontecer em agosto de 2011. No final de junho, o rapaz cego desde os dois anos, que faria parte da pesquisa, noticiou mudança para Minas Gerais. 0 pesquisador, envolvido com as burocracias de um estágio de pesquisa na Dinamarca, não conseguiu prospectar novos participantes antes de sua partida, outubro de 2011.

No retorno ao Brasil, janeiro de 2012, 0 primeiro trabalho realizado foi a busca incessante por sujeitos, ainda que apenas um, para fazer parte do estudo. Finais de março e 0 pesquisador ainda não havia encontrado ninguém, quando resolveu convidar um dos participantes da oficina realizada no MAM-SP, 0 escultor Rogério Ratão. Rogério, contudo, não era cego congênito; havia perdido a visão tardiamente, aos 18 anos. Mesmo incapaz de enxergar há mais de 20 anos, tinha, por certo, memória visual.

Foi então que o pesquisador notou o seguinte: John M. Kennedy já havia demonstrado que cegos congênitos são capazes de desenhar, inclusive formas tomadas unicamente como visuais, a exemplo da perspectiva. Inexistia, portanto, a necessidade de tentar "provar", ou referendar no plano empírico, algo que já estava relatado na literatura científica. 0 autor, portanto, cônscio da proposta exclusiva de examinar desenhos feitos pelo tato, ignorando questões a exemplo de memória ou graus de acuidade visual, se deu conta de que poderia trabalhar com sujeitos dotados de baixa visão ou mesmo videntes vendados. 


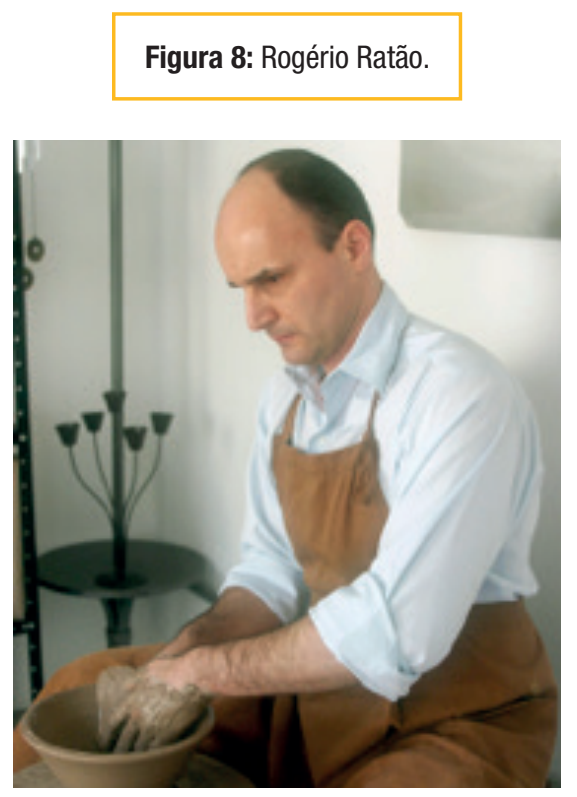

Ao ser convidado para o experimento, Rogério, prontamente, atendeu ao chamado. Assim, em junho de 2012, o pesquisador dirigiu-se ao ateliê do escultor e os experimentos foram realizados em uma única tarde. Escultor habilidoso, Rogério apresentava destreza no manuseio do kit, que lhe foi ofertado para experimentação por cerca de dez minutos, a fim de garantir alguma intimidade com o material, usado apenas no museu, meses atrás.
0 pesquisador dispunha de três objetos, Figuras 09,10 e 12, os quais deveriam ser desenhados ao modo de signos imagéticos: dois comuns - pilha e garrafa de vinho - e um cavalo de Dalarma, artesanato sueco totalmente desconhecido por Rogério. 0 objetivo era saber se, diante do novo, o sujeito seria capaz de perceber qualidades e, através de imagens imagéticas, transferi-las para a folha plástica. 
Figura 10: Garrafa de vinho.

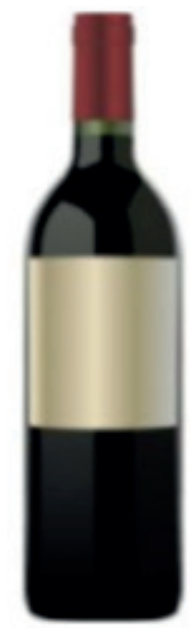

Figura 11: Rogério desenha garrafa de vinho.

Figura 12: Cavalo de Dalarma.

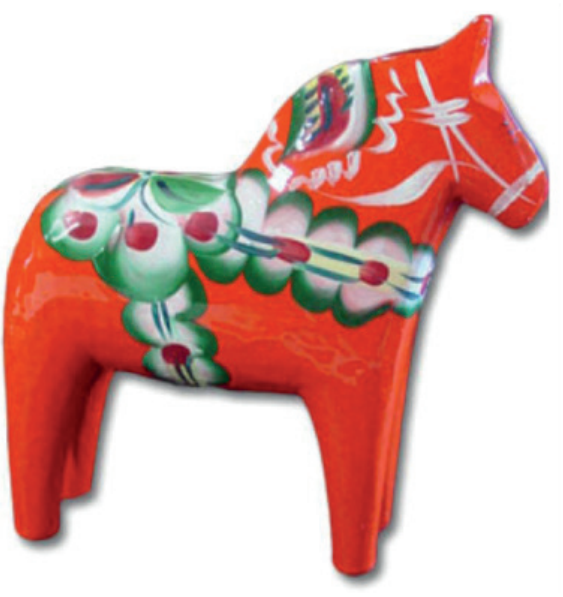




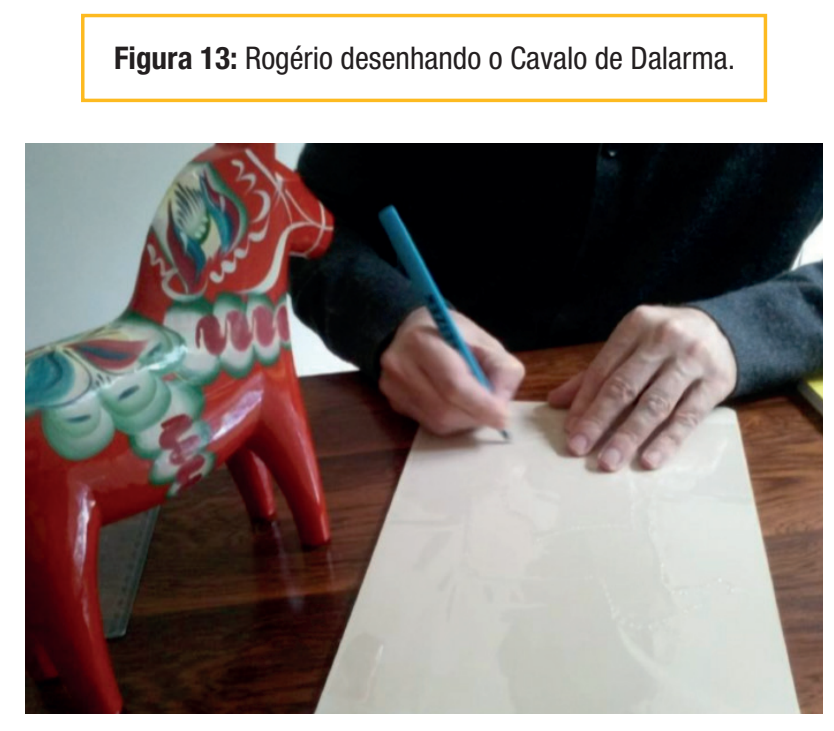

No caso do diagrama, Rogério definiu que faria um Espontaneamente, o escultor solicitou usar réguas mapa do piso inferior do seu ateliê (Figura 14). para a tarefa. 0 pesquisador não se opôs.

Figura 14: Rogério, munido de régua, faz mapa do piso inferior de seu ateliê, um sobrado.

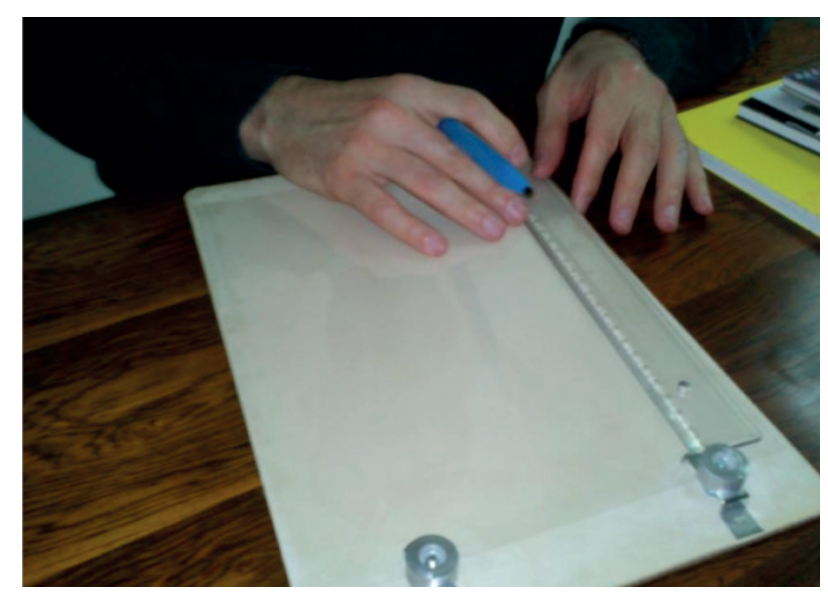

Quanto à produção de metáforas, definiu-se 0 uso de uma música instrumental, pois se julgou que vocais verbais poderiam criar, mais facilmente, a ideia de uma narrativa, induzindo a criação de desenhos ligados ao verbo e não ao som stricto sensu. Além disso, o pesquisador resolveu optar por música contemporânea, cujos sons não tivessem instrumentos musicais identificáveis. A composição "Clair de Lune", tocada no experimento do MAMSP, fez alguns sujeitos desenharem "pianos", ou "teclas de pianos", isto é, representar visualmente o som do piano que ouviam - uma relação indexical -, e não o mencionado som per se. Foi, assim, escolhida música do dueto alemão de electro 
house "Digitalism", intitulada "Taken away", especialmente criada em 2008 para um comercial de carros da marca "Mercedes".

A seguir, os desenhos resultantes dos experimentos serão analisados.

\section{Imagens imagéticas}

Antes do início da atividade, foi pedido ao sujeito que retratasse todos os objetos com a maior fidelidade possível. 0 pesquisador não os nomeou, deixando a identificação dos mesmos para Rogério. A seguir (Figura 17), pode ser contemplada a representação criada para a garrafa. Foi necessário tratá-la, a representação, a fim de tornar o desenho, visualmente, reprodutível, pelo motivo de ter sido confeccionado com caneta sem tinta sobre folha transparente. Ação similar foi desenvolvida para todas as imagens produzidas para o estudo.

\section{Figura 15}

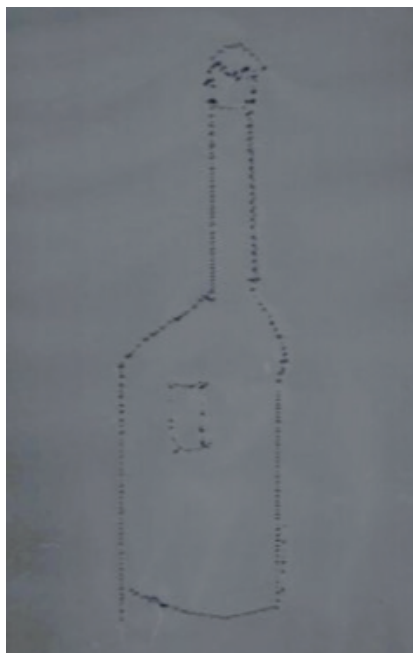

Como se percebe, há grande similaridade visual entre 0 desenho obtido e a fotografia da garrafa, de modo que se pode conjecturar que Rogério percebeu com o tato qualidades similares àquelas captáveis pelos olhos, e foi capaz de representá-las, no desenho háptico, de maneira também acessível à visão. Isso, algum grau, parece referendar a tese de que

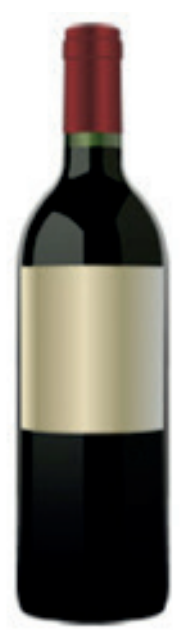

as quinas e bordas, qualidades espaciais/ indexicais retratadas pelos contornos e presentes na própria garrafa, são elementos acessíveis e acessados, maneira parecida, pelo sistema tátil e pela visão. Exame da ilustração feita para as pilhas apresentou resultado similar, como pode ser a seguir verificado: 


\section{Figura 16}
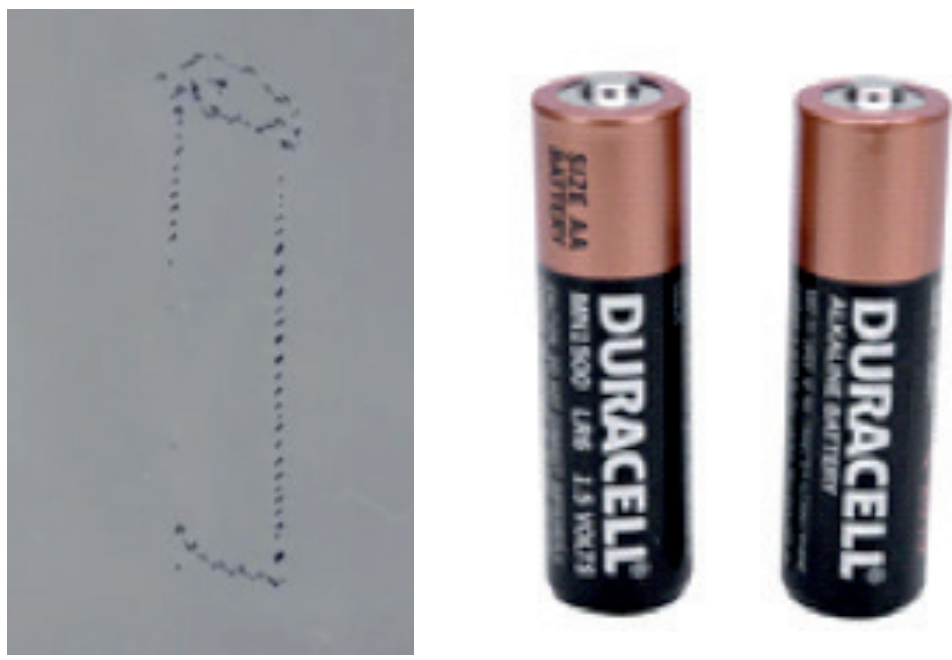

0 grande desafio, no entanto, seria aferir como Rogério desenharia o "Cavalo de Dalarma". 0 objeto, totalmente desconhecido, foi-lhe entregue, como os demais, sem que fosse previamente identificado pelo pesquisador.
Após rápido exame com as mãos, Rogério perguntou se era o caso de um cavalo, obtendo resposta positiva por parte do pesquisador. Logo, o sujeito iniciou seu desenho, chegando àquilo retratado a seguir.
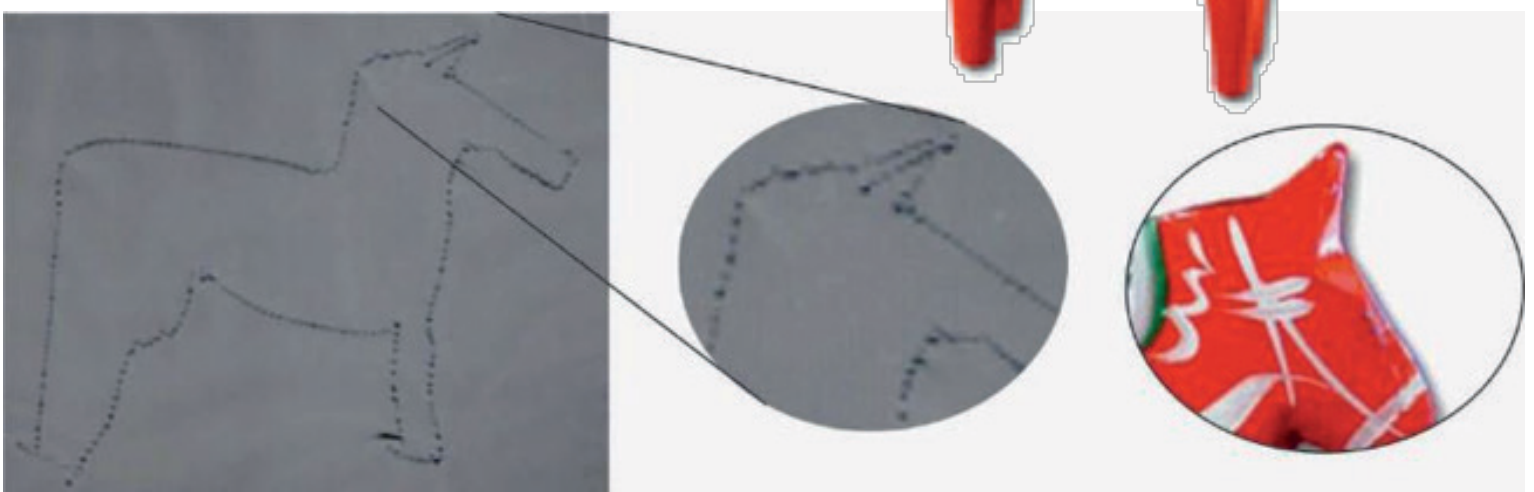
Conforme observável, Rogério conseguiu desenhar o cavalo, não apenas replicando os contornos capazes de identificar a imagem produzida com 0 animal, mas também atentando ao detalhe ou à qualidade, no que se refere aos contornos, peculiar apenas aos "Cavalos de Dalarma": as orelhas pontiagudas, destacadas na figura anterior. Isso permite sugerir, de fato, a possibilidade de se produzir representações tátil-visuais acessíveis, bilateralmente, para videntes e deficientes visuais, mesmo no caso de objetos inteiramente desconhecidos para os dois grupos. Tal propósito exige apenas conformar linhas visíveis que possam, também, responder à investigação háptica, isto é, criar descontinuidades háptico-ópticas em superfícies contínuas.

\section{Imagens diagramáticas}

0 sujeito foi convidado a desenhar um percurso que habitualmente fizesse ou um mapa. Aparentemente entendendo, modo intuitivo, que o pesquisador desejava a reprodução de imagem diagramática, Rogério perguntou se poderia fazer uma espécie de "planta baixa" do piso inferior de seu ateliê. 0 pesquisador concordou, dizendo a Rogério que a planta não deixava de ser um mapa. Equipamento em mãos, o sujeito começou a desenhar e, prontamente, parou o processo. Questionou se poderia pegar uma das réguas localizadas sobre a sua mesa de trabalho e usá-la para facilitar o processo. "A mão é troncha, mas a parede não é", disse Rogério, às gargalhadas. 0 pesquisador não fez qualquer objeção e, de posse da régua, em menos de três minutos, o sujeito elaborou o desenho a seguir:

Figura 18: A planta do ateliê.

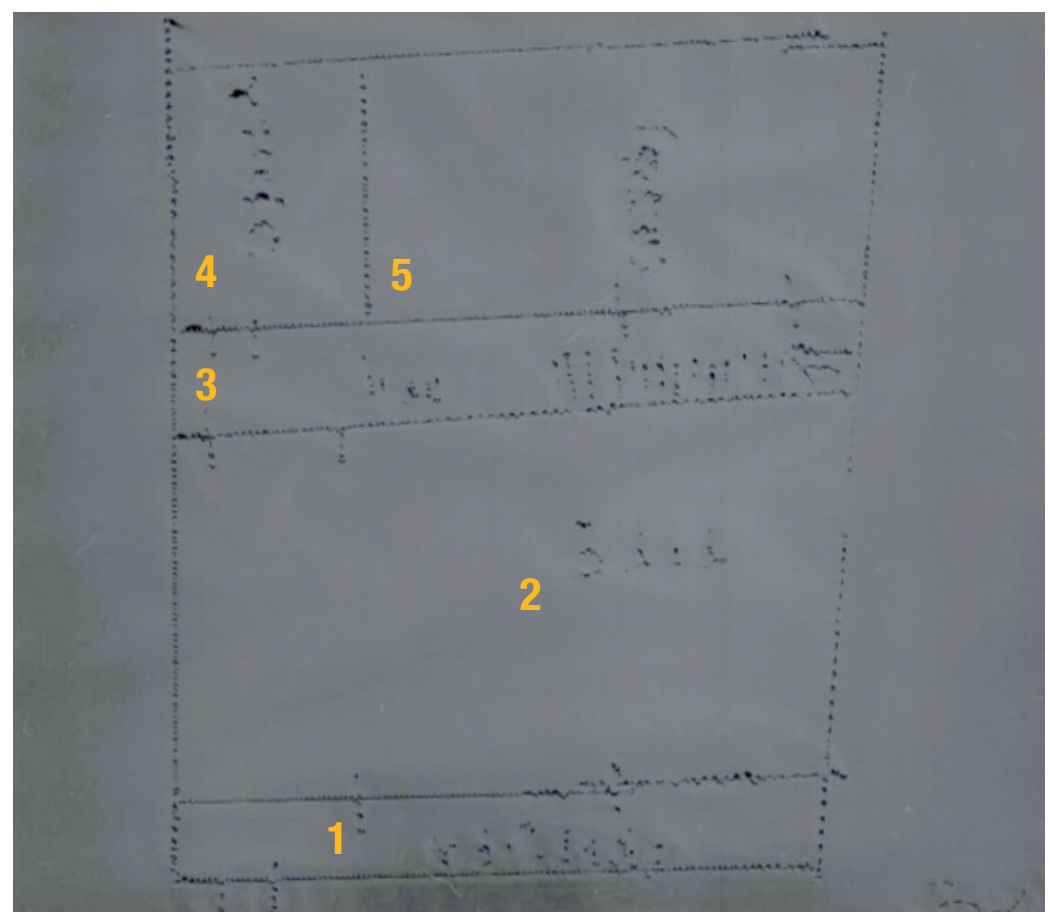


A posteriori, ao analisar a imagem, o pesquisador percebeu que, para cada divisão, Rogério havia escrito o nome do ambiente correspondente: 1) entrada; 2) hall; 3) corredor; 4) banheiro; 5) cozinha. Infelizmente, na reprodução escaneada, as grafias dos cômodos, exceção de "hall", ficaram ilegíveis. 0 pesquisador conhece bem 0 ateliê de Rogério e pode aferir que o mapa desenhado é capaz de descrever, visual e tatilmente, 0 ambiente retratado com elevada fidelidade diagramática, inclusive de proporção. Isso está de acordo com aquilo que Nöth (1998), em sua Cartossemiótica, caracterizou como próprio dos mapas: 0 respeito às leis de projeção espacial.

De um lado, o experimento levanta a excitante questão de que 0 espaço pode ser projetado - sentido geométrico, a perspectiva inclusa - não apenas a partir de estímulos visuais, mas também táteis. Dito noutras palavras: as quinas e bordas do espaço são elas mesmas fontes de excitações capazes de serem, analogamente, entendidas por tato e visão. São também causadoras de representações análogas, nas quais a face convencional possui baixo grau de relevância. Isso sugere, por exemplo, que noções como as do filósofo norte-americano Nelson Goodman (1968, p. 12), segundo a qual a perspectiva seria predicado visual arbitrário, estão erradas. No sentido oposto e de acordo com Nöth (1998), um mapa, para funcionar, deve respeitar, indexicalmente, o espaço, seu objeto.

\section{Imagens metafóricas}

Finalmente, Rogério, certa desconfiança, foi informado pelo pesquisador que deveria “desenhar uma música”. De imediato, ele questionou se deveria desenhar uma cena $d a$ música, ou objeto que tivesse relação com ela. 0 pesquisador, simplesmente, falou: "Você vai escutar a reprodução e desenhar aquilo que julgar pertinente". Forneceram-se, então, fones de ouvido, e a composição foi tocada para o sujeito.

Finda a melodia, Rogério, excitado talvez pelo som, talvez por algum tipo de ansiedade ou medo de "desenhar uma música", perguntou se poderia ouvir a composição uma segunda vez, no que foi imediatamente atendido. Então, ainda com a música sendo tocada, ele iniciou, espontaneamente, o desenho que pode ser a seguir verificado, feito em aproximados sete minutos, com algumas pausas e retomadas da atividade, sempre por vontade do próprio sujeito. Certo momento, Rogério disse ter acabado o desenho (Figura 19). 0 pesquisador perguntou se ele poderia descrever 0 traçado e ter a sua descrição gravada para análise. 
Figura 19: A representação de Rogério para "Taken away".

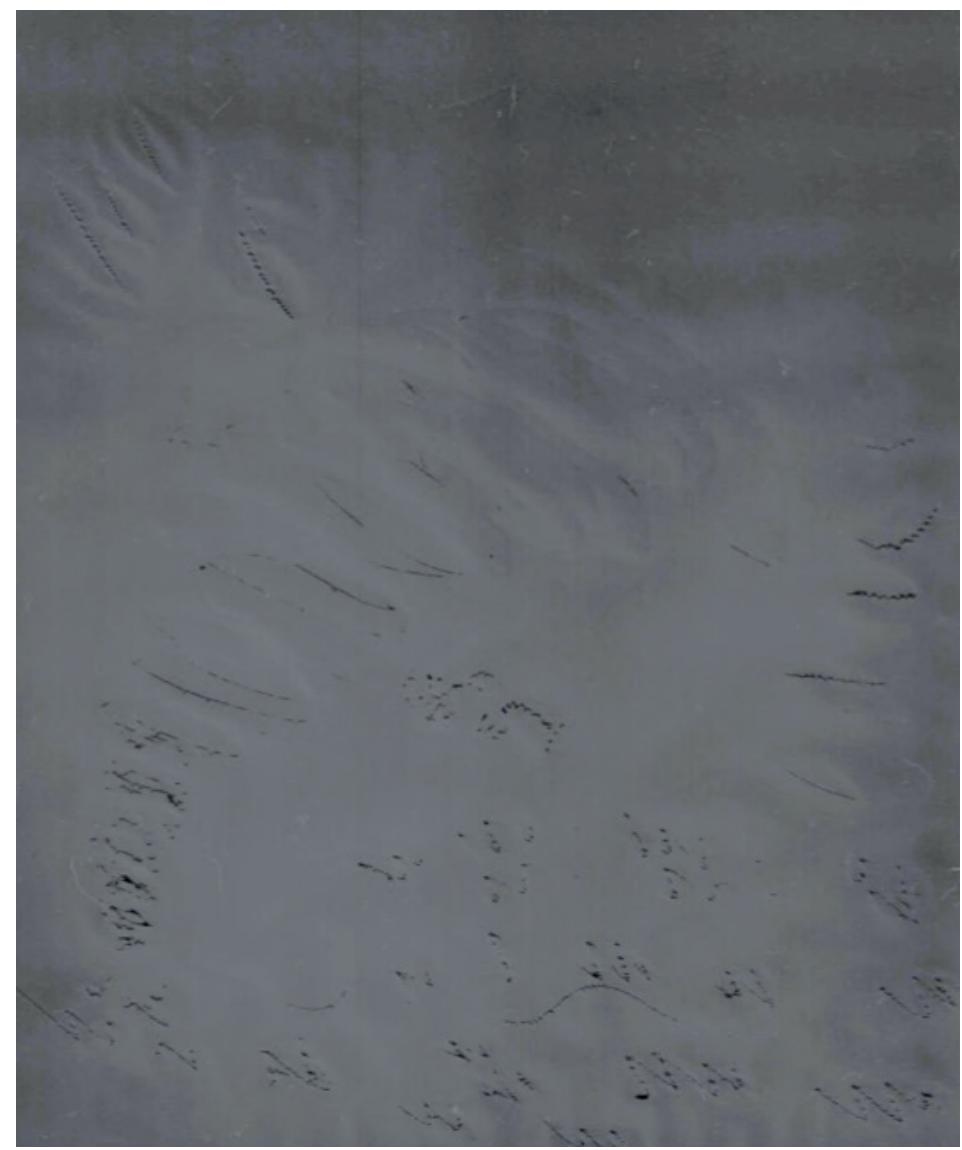

Conforme se pode ouvir no áudio da entrevista gravada, o pesquisador pergunta a Rogério como ele sentiu a música e baseado em quais qualidades da música ele havia realizado o desenho. Rogério respondeu: "Muito em cima do ritmo mesmo. No começo é uma coisa assim frenética, mas assim eu senti uma coisa no piso, (...) e depois o ritmo faz a cabeça voar, numa espiral indo largo da esquerda para a direita (...). E dali isso refletindo pros lados dessa espiral".

Como se percebe, a escolha do áudio instrumental contemporâneo, muito abstrato, revelou-se acertada. Por ser predominantemente icônica em um nível imagético, essa música consegue despertar sensações. Primeiro, Rogério falou sobre sentir "uma coisa no piso", quando ouviu a composição, apenas, com fones de ouvido; de modo que não exisitu qualquer "efeito real" sobre 0 chão causado pela reprodução do áudio. Depois, o sujeito falou de algo que fazia a "cabeça voar" em espiral larga, da esquerda para a direita. A música, ela mesma, contudo, não fazia qualquer referência aos elementos a ela associados. Manipulando-se 0 contraste, a luminosidade e a intensidade do desenho produzido, chegou-se à figura a seguir, que revela algo impressionante: 
Figura 20: Imagem metafórica manipulada.

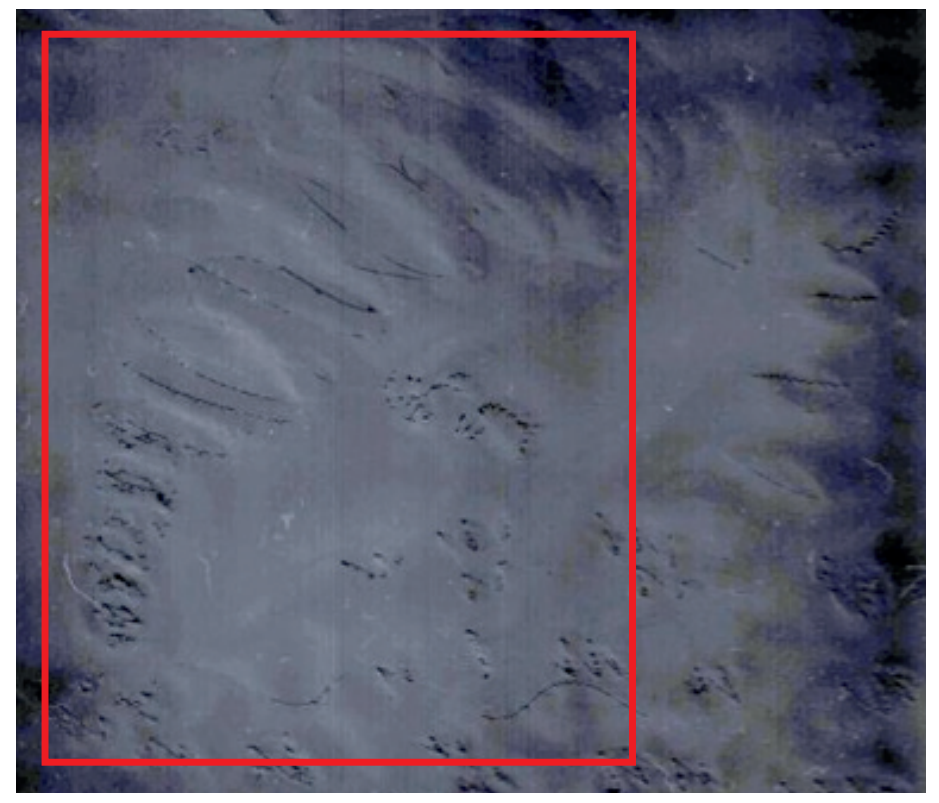

Pode-se, na área demarcada, verificar uma espécie de espiral, menor embaixo e mais aberta na parte de cima, que parece ir da esquerda para a direita. Isso significa que o desenho representa, não como metáfora, mas sim diagrama, as sensações que Rogério descreveu como perceptíveis, por ele, na música. Ainda que alguém não conheça a melodia, pode, interpretando o desenho e sabendo que este se reporta à composição, inferir que esta se assemelha a um redemoinho ou "espiral" que se move da esquerda para a direita. Mesmo que 0 resultado não tenha sido o esperado - a produção de uma metáfora -, evidenciou-se algo fundamental: ao se traduzir uma linguagem em outra, no caso som em desenho, a representação não poderá, nunca, ser uma imagem, pois é impossível, por exemplo, copiar visualmente qualidades sonoras; mas a representação deverá ser obrigatoriamente um digrama, isto é, a representação por analogia de relações internas, ou um signo metafórico, convencionado.

\section{Alguns aprendizados e questões}

Dotado do aparato técnico adequado e da explicação apropriada, o sujeito deste estudo produziu desenhos sem 0 auxílio visual, representações estas facilmente interpretáveis pela visão. Isso parece confirmar tanto a hipótese de alguma correspondência entre os dados providos à mente pelas experiências visual e háptica, quanto a suposição de que é possível desenvolver uma linguagem gráfica igualmente acessível aos olhos e ao tato.

A base desta linguagem, acredita-se, deve ser o desenho em contorno, cuja expressão gráfica representa as quinas e bordas responsáveis 
pela percepção de limites, descontinuidades capazes de permitir a diferenciação dos objetos, reais ou imaginários, uns dos outros e, assim, 0 entendimento espacial (Santos, 2012). Se tais desenhos tiverem não apenas contornos visíveis, mas também tangíveis, poderão ser enxergados como um todo ou examinados aos poucos pelas mãos e, desse modo, analogamente compreendidos (cf. Santos, 2015a).

As imagens feitas por Rogério Ratão, que, por ser escultor, tem habilidades manuais desenvolvidas, podem dar margens a questionar se outro sujeito, cego desde sempre e sem a desenvoltura do artista, forneceria resultados similares. Sobre isso, é necessário dizer três coisas: 1) Kennedy (1993), em seus estudos, aferiu, empiricamente, que cegos congênitos desenham de modo similar aos videntes, havendo ampla literatura sobre a temática; 2) 0 estudo feito, qualitativo, realmente não prova nada, mas indica algo; 3) um vidente adulto que nunca tivesse desenhado ou visto imagens, provavelmente, também teria grandes dificuldades para fazê-las; a cegueira, per se, ao menos no caso dos desenhos em contorno, deixa, pois, de ser condição limitadora.

Uma inovação dos experimentos aqui realizados foi a de trazer dados que sugerem para 0 tato a produção de signos gráficos diagramáticos e metafóricos - aqui lembrando o pré-teste com música feito no MAM-SP - análogos aos visuais, pois a literatura mundial dedicada a investigar a matéria encontra-se centrada na produção de experimentos onde se examinam, quase exclusivamente, imagens imagéticas. Percebeuse, também, a importância de se praticar a audiodescrição (Santos, 2015b), cujos inputs são fundamentais para transmitir aos privados da visão experiências, referências e instruções visuais necessárias à confecção de desenhos; igualmente, ficou clara a necessidade de se usar instrumentos adequados à criação de representações gráficas hápticas, equipamentos ao momento inexistentes no Brasil, mas fundamentais.

0 autor, palavras finais, defende que as imagens não são signos necessariamente visuais e podem, com os mecanismos adequados, ser tornadas acessíveis a pessoas cegas sem ações mirabolantes. 0 que falta é aceitar que os privados da visão não estão privados das imagens e permitir-lhes, como é ofertado aos videntes, a construção de repertório gráfico e a realização, desde a mais tenra idade, de figuras. A principal questão, talvez, seja como realizar isso de modo adequado, sobremaneira tendo em mente que, muitos casos, videntes desenvolvem metodologias e equipamentos sem incluir cegos e pessoas com baixa visão em tais processos.

\section{Referências}

AUGUSTO, Carl R. (1992). Foreword. In: EDMAN, Polly K. Tactile graphics. New York: American Foundation for the Blind, 1992.

BRITO, P. R.; VEITZMAN, S. Causas de cegueira e baixa visão em crianças. Arquivos Brasileiros de Oftalmologia, São Paulo, v. 63, n. 1, p. 49-54, 2000 
DUARTE, M. L. B. Diário de Manu: Revelando a aprendizagem do desenho por uma criança cega.

Revista de Investigação em Artes. Florianópolis, v. 01, p. 1-13, 2004.

\section{0 desenho do pré-adolescente:}

características e tipificação. Dos aspectos gráficos à significação nos desenhos de narrativa. 1995. 205

f. Tese (Doutorado em Artes) - Escola de Comunicação e Artes, USP, São Paulo, 1995.

EDMAN, Polly K. Tactile graphics. New York: American Foundation for the Blind, 1992.

GO0DMAN, Nelson. Languages of Art: An Approach to a Theory of Symbols. Indianapolis and New York: The Bobbs-Merrill Company.

IBGE. Censo Demográfico 2010. Disponível em: $<$ http://www.censo2010.ibge.gov.br>. Acesso em junho de 2011.

KENNEDY, J.M. Drawing and the blind. New Haven: Yale Press, 1993.

KENNEDY, J. M., JURICEVIC, I. Blind man draws using convergence in three dimensions. Psychonomic Bulletin and Review, 13 (3), 506-509, 2006.

KLATZKY, R.L., LEDERMAN, S.J., METZGER, V. Identifying objects by touch: An "expert system". Perception \& Psychophysics, 37(4), 299-302, 1985.

NÖTH, W. Cartossemiótica. In: A. Oliveira \& Y. Fechine (eds.). Visualidade, urbanidade, intertextualidade. São Paulo: Hacker Editores, 1998.

PEIRCE, Charles S. (1931-1966). The collected papers of Charles S. Peirce, 8 vols., C. Hartshorne, P. Weiss \& A. W. Burks (eds.). Cambridge: Harvard University Press. [Reference to Peirce's papers will be designated CP followed by volume and paragraph number.]

SANTOS, Marcelo. A semiotic approach to blind wayfinding: some primary conceptual standpoints. meta-carto-semiotics, v. 2, p. 1-8, 2009.
Considerações semióticas sobre a visão e 0

tato. Líbero (FACASPER), v. 18, p. 35-44, $2015 \mathrm{a}$.

Hipertrofia da visão- inflação do

imaginário: um estudo empírico sobre a produção e recepção de sentidos pelo corpo da mulher cega numa sociedade escopofílica. 2008. 145 f. Dissertação (Mestrado em Comunicação e Semiótica) - PUC-SP, São Paulo, 2008.

Por uma nova ética audiodescritiva: a recriação como procedimento. Bakhtiniana: Revista de Estudos do Discurso, v. 10, p. 222-234, 2015b. Touch, vision, and diagrammatical reasoning. Semiotica (Berlin), v. 2012, p. 253-263, 2012. 


\section{Graphic language for the visually impaired: first empirical results}

\section{Abstract}

This article presents the first empirical results of the research project initiated in 2008, which examines the production of images by the blind. The project has a twofold objective. One, to question certain canons of visual language to prove that a number of its principles are learned without the assistance of vision, thus showing that they are not exclusively characteristic of visuality; second, the study seeks to propose methodologies for constructing tactile images, which are equally accessible to those with or without visual handicaps. The facts stated here were culled from a qualitative study undertaken with a visually impaired subject who was invited to illustrate imagetic, diagrammatic, and metaphoric images, interpreted within this text with the help of Peircean semiotics.

\section{Keywords}

Blindness. Graphic language. Peircean semiotics.

\section{El lenguaje gráfico de los que no ven: primeros resultados empíricos}

\section{Resumen}

Este artículo presenta los primeros resultados empíricos de un proyecto de investigación iniciado el 2008, que examina la producción de imágenes por los ciegos. El proyecto tiene un doble objetivo. Primero, cuestionar ciertos cánones del lenguaje visual para demostrar que muchos de sus principios se aprenden sin la ayuda de la visión, lo que demuestra que no son características exclusivas de la visualidad. En segundo lugar, el estudio busca proponer metodologías para la construcción de imágenes táctiles, que son igualmente accesibles para las personas con 0 sin discapacidad visual. Los datos indicados aquí fueron generados en un estudio cualitativo realizado con un sujeto ciego que fue invitado para ilustrar imágenes imagéticas, esquemáticas, y metafóricas, interpretadas dentro de este texto con la ayuda de la semiótica de Peirce.

\section{Palabras clave}

Ceguera. Lenguaje gráfico. Semiótica de Peirce. 


\section{Expediente}

A revista E-Compós é a publicação científica em formato eletrônico da Associação Nacional dos Programas de Pós-Graduação em Comunicação (Compós). Lançada em 2004, tem como principal finalidade difundir a produção acadêmica de pesquisadores da área de Comunicação, inseridos em instituições do Brasil e do exterior.

\section{E-COMPÓS I www.e-compos.org.br I E-ISSN 1808-2599}

Revista da Associação Nacional dos Programas de Pós-Graduação em Comunicação. Brasília, v.19, n.2, maio/ago. 2016. A identificação das edições, a partir de 2008, passa a ser volume anual com três números. Indexada por Latindex I www.latindex.unam.mx

\section{CONSELHO EDITORIAL}

\section{Alexandre Farbiarz, Universidade Federal Fluminense, Brasi}

Alexandre Rocha da Silva, Universidade Federal do Rio Grande do Sul, Brasil Ana Carolina Escosteguy, Pontifícia Universidade Católica do Rio Grande do Sul, Brasil Ana Carolina Rocha Pessôa Temer, Universidade Federal de Goiás, Brasil Ana Regina Barros Rego Leal, Universidade Federal do Piauí, Brasil Andrea França, Pontifícia Universidade Católica do Rio de Janeiro, Brasil André Luiz Martins Lemos, Universidade Federal da Bahia, Brasil Antonio Carlos Hohlfeldt, Pontifícia Universidade Católica do Rio Grande do Sul, Brasil Arthur Ituassu, Pontifícia Universidade Católica do Rio de Janeiro, Brasil Álvaro Larangeira, Universidade Tuiuti do Paraná, Brasil

Ângela Freire Prysthon, Universidade Federal de Pernambuco, Brasil César Geraldo Guimarães, Universidade Federal de Minas Gerais, Brasil Cláudio Novaes Pinto Coelho, Faculdade Cásper Líbero, Brasil Daisi Irmgard Vogel, Universidade Federal de Santa Catarina, Brasil Denize Correa Araujo, Universidade Tuiuti do Paraná, Brasil Eduardo Antonio de Jesus, Pontifícia Universidade Católica de Minas Gerais, Brasil Daniela Zanetti, Universidade Federal do Espírito Santo, Brasil Eduardo Vicente, Universidade de São Paulo, Brasil

Elizabeth Moraes Gonçalves, Universidade Metodista de São Paulo, Brasil Erick Felinto de Oliveira, Universidade do Estado do Rio de Janeiro, Brasil Francisco Elinaldo Teixeira, Universidade Estadual de Campinas, Brasil Francisco Paulo Jamil Almeida Marques, Universidade Federal do Paraná, Brasil Gabriela Reinaldo, Universidade Federal do Ceará, Brasil

Goiamérico Felício Carneiro Santos, Universidade Federal de Goiás, Brasil Gustavo Daudt Fischer, Universidade do Vale do Rio dos Sinos, Brasil Herom Vargas, Universidade Municipal de São Caetano do Sul, Brasil Itania Maria Mota Gomes, Universidade Federal da Bahia, Brasil Janice Caiafa, Universidade Federal do Rio de Janeiro, Brasil Jiani Adriana Bonin, Universidade do Vale do Rio dos Sinos, Brasil
José Afonso da Silva Junior, Universidade Federal de Pernambuco, Brasil José Luiz Aidar Prado, Pontifícia Universidade Católica de São Paulo, Brasil Juçara Gorski Brittes, Universidade Federal de Ouro Preto, Brasil Kati Caetano, Universidade Tuiuti do Paraná, Brasil Lilian Cristina Monteiro França, Universidade Federal de Sergipe, Brasil Liziane Soares Guazina, Universidade de Brasilia, Brasil Luíza Mônica Assis da Silva, Universidade de Caxias do Sul, Brasil Luciana Miranda Costa, Universidade Federal do Pará, Brasil Malena Segura Contrera, Universidade Paulista, Brasil Monica Martinez, Universidade de Sorocaba, Brasil Maria Ataide Malcher, Universidade Federal do Pará, Brasil Marcia Tondato, Escola Superior de Propaganda e Marketing, Brasil Marcel Vieira Barreto Silva, Universidade Federal da Paraiba, Brasil Maria Clotilde Perez Rodrigues, Universidade de São Paulo, Brasil Maria das Graças Pinto Coelho, Universidade Federal do Rio Grande do Norte, Brasil Mauricio Ribeiro da Silva, Universidade Paulista, Brasil

Mauro de Souza Ventura, Universidade Estadual Paulista, Brasil Márcio Souza Gonçalves, Universidade do Estado do Rio de Janeiro, Brasil Micael Maiolino Herschmann, Universidade Federal do Rio de Janeiro, Brasil Mirna Feitoza Pereira, Universidade Federal do Amazonas, Brasil Nísia Martins Rosario, Universidade Federal do Rio Grande do Sul, Brasil Potiguara Mendes Silveira Jr, Universidade Federal de Juiz de Fora, Brasil Regiane Regina Ribeiro, Universidade Federal do Paraná, Brasil Rogério Ferraraz, Universidade Anhembi Morumbi, Brasil Rose Melo Rocha, Escola Superior de Propaganda e Marketing, Brasil Rozinaldo Antonio Miani, Universidade Estadual de Londrina, Brasil Sérgio Luiz Gadini, Universidade Estadual de Ponta Grossa, Brasil Simone Maria Andrade Pereira de Sá, Universidade Federal Fluminense, Brasil Veneza Mayora Ronsini, Universidade Federal de Santa Maria, Brasil Walmir Albuquerque Barbosa, Universidade Federal do Amazonas, Brasil
COMISSÃO EDITORIAL Eduardo Antonio de Jesus, Pontifícia Universidade Católica de Minas Gerais, Brasil I Osmar Gonçalves dos Reis Filho, Universidade Federal do Ceará, Brasi

CONSULTORES AD HOC Alexandre Almeida Barbalho, Universidade Estadual do Ceará, Brasil | Alexandre Rocha da Silva, Universidade Federal do Rio Grande do Sul, Brasil | Bruno Souza Leal, Universidade Federal de Minas Gerais, Brasil I Carlos Eduardo Franciscato, Universidade Federal do Sergipe, Brasil I Eneus T. Barreto Filho, Universidade de São Paulo, Brasil I Felipe da Costa Trotta, Universidade Federal Fluminense, Brasi | Henrique Codato, Universidade Federal do Ceará, Brasil I Ines S. Vitorino Sampaio Universidade Federal do Ceará, Brasil I Jairo Getulio Ferreira, Universidade do Vale do Rio dos Sinos, Brasil I Juliana Freire Gutmann, Universidade Federal da Bahia, Brasil | Júlio César M. Pinto, Pontifícia Universidade Católica de Minas Gerais, Brasil I Lucrecia D. Ferrara, Pontifícia Universidade Católica de São Paulo, Brasil I Marcio V. Serelle, Pontifícia Universidade Católica de Minas Gerais, Brasil I Maria Ignes C. Magno, Universidade Anhemb Morumbi, Brasil I Maria Lilia Dias de Castro, Universidade Federal de Santa Maria, Brasil Mozahir S. Bruck, Pontifícia Universidade Católica de Minas Gerais, Brasil I Potiguara M. da Silveira Junior, Universidade Federal de Juiz de Fora, Brasil I Sandra Maria L. P. Gonçalves, Universidade Federal do Rio Grande do Sul, Brasil I Suzana Kilpp, Universidade do Vale do Rio dos Sinos, Brasil I Tiago Q. Fausto Neto, Universidade de Brasília, Brasil I Vera Regina V. Franca, Universidade Federal de Minas Gerais, Brasil I Virginia P. S. Fonseca, Universidade Federal do Rio Grande do Sul, Brasil

EQUIPE TÉCNICA ASSISTENTE EDITORIAL Márcio Zanetti Negrini REVISÃo DE TEXTOS Press Revisão I EDITORAÇÃO ELETRÔNICA Roka Estúdio

\section{COMPÓS I www.compos.org.br}

Associação Nacional dos Programas de Pós-Graduação em Comunicação

Presidente

Edson Fernando Dalmonte

Programa de Pós-Graduação em Comunicação

e Cultura Contemporânea - UFBA

edsondalmonte@uol.com.br

Vice-presidente

Cristiane Freitas Gutfreind

Programa de Pós-Graduação em Comunicação Social - PUC-RS cristianefreitas@pucrs.br

Secretário-Geral

Rogério Ferraraz

Programa de Pós-Graduação em Comunicação

Universidade Anhembi Morumbi

rogerioferraraz@anhembimorumbi.edu.br

CONTATO I revistaecompos@gmail.com 